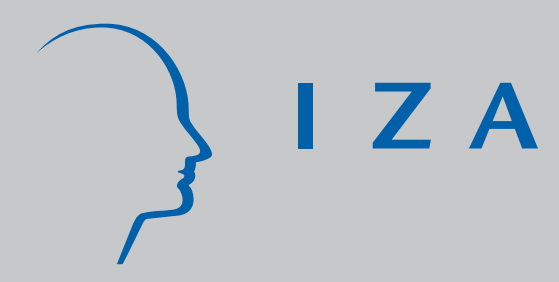

IZA DP No. 468

The Impact of Risk Aversion, Role Models, and the Regional Milieu on the Transition from Unemployment to Self-Employment: Empirical Evidence for Germany

J oachim Wagner

April 2002 


\title{
The Impact of Risk Aversion, Role Models, and the Regional Milieu on the Transition from Unemployment to Self-Employment: Empirical Evidence for Germany
}

\author{
Joachim Wagner \\ University of Lueneburg and IZA, Bonn
}

Discussion Paper No. 468

April 2002

\author{
IZA \\ P.O. Box 7240 \\ D-53072 Bonn \\ Germany \\ Tel.: +49-228-3894-0 \\ Fax: +49-228-3894-210 \\ Email: iza@iza.org
}

This Discussion Paper is issued within the framework of IZA's research area Mobility and Flexibility of Labor. Any opinions expressed here are those of the author(s) and not those of the institute. Research disseminated by IZA may include views on policy, but the institute itself takes no institutional policy positions.

The Institute for the Study of Labor (IZA) in Bonn is a local and virtual international research center and a place of communication between science, politics and business. IZA is an independent, nonprofit limited liability company (Gesellschaft mit beschränkter Haftung) supported by the Deutsche Post AG. The center is associated with the University of Bonn and offers a stimulating research environment through its research networks, research support, and visitors and doctoral programs. IZA engages in (i) original and internationally competitive research in all fields of labor economics, (ii) development of policy concepts, and (iii) dissemination of research results and concepts to the interested public. The current research program deals with (1) mobility and flexibility of labor, (2) internationalization of labor markets, (3) welfare state and labor markets, (4) labor markets in transition countries, (5) the future of labor, (6) evaluation of labor market policies and projects and (7) general labor economics.

IZA Discussion Papers often represent preliminary work and are circulated to encourage discussion. Citation of such a paper should account for its provisional character. A revised version may be available on the IZA website (www.iza.org) or directly from the author. 


\section{ABSTRACT \\ The Impact of Risk Aversion, Role Models, and the Regional Milieu on the Transition from Unemployment to Self-Employment: Empirical Evidence for Germany*}

The focus of this paper is on the choice of the unemployed between becoming an entrepreneur or not. It contributes to the literature by empirically investigating two hitherto neglected issues: What is the impact of risk aversion and personal contact with a role model in shaping the decision to become an entrepreneur (controlling for standard demographic variables, i.e. sex, age, and education)? And given the personal characteristics and attitudes, how does the regional 'entrepreneurial milieu' affect the decision to start a new business out of unemployment? The econometric study is based on data from a recent representative survey of the population in ten German planning regions. We use a version of the probit model that takes care of the regional stratification of the data, and the results of the nonlinear models are carefully interpreted and illustrated. We show that a high degree of risk aversion, and lack of personal contact with a young entrepreneur, both reduce the probability of starting one's own business. A favourable 'regional entrepreneurial milieu' (proxied by higher levels of current start-up activity and larger shares of unemployed among the starters in a region) has a positive effect on the individual propensity to step into self-employment. All these impacts are not only statistically significant, but economically important, too.

JEL Classification: J23, R12

Keywords: entrepreneurship, unemployment, Germany, regional milieu

Joachim Wagner

University of Lueneburg

Institute of Economics

D-21332 Lueneburg

Germany

Tel.: +49 4131-78-2330

Fax: +49 4131-78-2026

Email: wagner@uni-lueneburg.de

\footnotetext{
* Research for this paper was done as part of the project Regional Entrepreneurship Monitor REM Germany financially supported by the German Research Foundation under grant number WA 610/2-1. This project is conducted jointly with Rolf Sternberg (University of Cologne, Germany) who is supported with grant number STE 628/7-1.
} 


\section{Motivation}

Reliable data from official statistics on new firm formation, and on the persons founding these firms, are lacking in Germany. However, a recently completed project that performed a careful comparison of four data bases providing information on startup activities led to an estimated number of some 310.000 entries per year in the private sector in the period 1996 - 1998 (Fritsch et al. 2001). The comparison project just mentioned did not look at characteristics of the founders. A case in point is that we do not know how many of the new firms were founded by people who were unemployed before. We know, however, that in the recent past some 100.000 (former) unemployed persons per year received so-called "bridging allowances" (or Überbrückungsgeld) - money from the federal labor services which is paid during the first six month of self-employment to help to start a business out of unemployment (for details, see Wießner 2000). Given that a very high (though unknown) share of founders who start out of unemployment receive these bridging allowances, 100.000 per year seems to be an appropriate estimate for the number of transitions from unemployment to self-employment in Germany today. With 310.000 new private firms per year according to the consensus estimate reported above this means that the share of formerly unemployed among the founders of new firms is 32.26 percent.

Even if this share of roughly one third is exaggregated due to a too low denominator (because very small owner-run businesses with no employees might be underreported in the statistics used to compute the estimate of the number of new firms per year) we can argue that, on the one hand, business start-ups out of unemployment form an important part of new firms in Germany today. On the other hand, the ca. 100.000 founders who step out of unemployment into self-employment per year are only a tiny fraction of the ca. 4 million registered (plus a large number of non-registered) unemployed, and increasing the number of unemployed who become self-employed can only be the notorious drop on a hot stone in the fight against unemployment. Investigations of the determinants and consequences of the transition from unemployment to self-employment are, therefore, a topic that is more important for research in entrepreneurial activities, and less so for active labor market policies to combat unemployment.

Hitherto only a few empirical studies based on German data were published that look at start-ups out of unemployment:

- Pfeiffer (1999) uses data for individuals from three waves of the German Mikrozensus (a one percent sample of the population) to investigate the differences between people who are looking for a new occupation in either self-employment or in paid employment. He uses these data to estimate the potential number of future self-employed (among those who are currently either unemployed or employed).

- Wießner $(2000,2001)$ uses data for individuals who received bridging allowances to investigate success factors that determine survival and growth of start-ups by former unemployed.

- Pfeiffer and Reize (2000a) compare firm survival and employment growth of start-ups by unemployed and others based on firm data.

- Pfeiffer and Reize (2000b) look at differences in the socioeconomic characteristics of people stepping from unemployment to self-employment and dependent employment using data from the 
German Socioecionomic Panel (GSOEP). In Reize (2000) the stability of self-employment amo ng former unemployed is investigated, too.

While a central topic of these studies is the success or failure of start-ups by the unemployed, this paper's focus is on the choice of the unemployed between becoming an entrepreneur or not. It contributes to the literature by empirically investigating two hitherto neglected issues:

- What is the role played by risk aversion and personal contact with a role model in shaping the decision to become an entrepreneur (controlling for standard demographic variables, i.e. sex, age, and education)?

- Given the personal characteristics and attitudes, how does the regional 'entrepreneurial milieu' affect the decision to start a new business out of unemployment?

Our econometric study is based on data from a recent representative survey of the population in ten German planning regions. We use a version of the probit model that takes care of the regional stratification of the data, and the results of the nonlinear models are carefully interpreted and illustrated.

The rest of the paper is organized as follows: Section 2 introduces the survey data used, section 3 gives empirical information on the extent of entrepreneurship activities by unemployed persons in German regions, section 4 discusses results from an econometric investigation of the individual determinants of becoming a nascent entrepreneur out of unemployment and the role played by the regional milieu, and section 5 concludes.

\section{The Regional Entrepreneurship Monitor (REM) Germany 2001 survey}

The data used in this paper are taken from a survey of the German population aged 14 years or older that was conducted using computer assisted telephone interviewing by TNS EMNID, a leading German opinion research institute, in the summer of 2001. This survey is part of the research project Regional Entrepreneurship Monitor REM Germany which focuses on the extent of the difference in entrepreneurial activities between regions in Germany, its determinants, and its consequences for regional development. ${ }^{1}$

In 10 (out of 97) so-called planning regions (or Raumordnungsregionen, see Bundesamt für Bauwesen und Raumordnung, 2001) a random sample of 1.000 people was interviewed, leading to a data set with 10.000 cases. $^{2}$ The questionnaire ${ }^{3}$ asked for socio-demographic characteristics (sex, age, education, maritial status, size of household, employment status, income) and a number of items related to entrepreneurial activities (e.g., whether the interviewee is the owner of a firm that is currently actively run by her or him, whether she/he is currently engaged in starting an own business). This data set gives a snapshot of activities and attitudes related to self-employment and new firm formation in the 10 regions

\footnotetext{
${ }^{1}$ For further information about the REM project see Japsen and Bergmann (2001). REM is closely related to GEM, the Global Entrepreneurship Monitor, a multi-country study that investigates the same topics at a national level (see Reynolds et al., 2000).

2 The data will be made available for public scientific use after the completion of the REM project.

3 An English version of the questionnaire is not yet available; a German version is available from the author on request.
} 
in the Summer of 2001. Even if we can not claim that the data are representative for Germany as a whole, the regions were selected in such a way that they mirror the spatial structure with regard to old and new federal states (i.e., western and eastern Germany), highly industrialized versus more rural regions, center and periphery, etc. With a pinch of salt information relating to the average in the selected regions can be considered to be a valid instrument for information on Germany as a whole.

\section{Nascent entrepreneurs out of unemployment in selected German regions}

In the survey discussed in the former section the interviewee was asked whether she/he is (alone or with others) actively involved in starting a new business that will (as a whole or in part) belong to her/him, and whether this business did not pay full time wages or salaries for more than three months to anybody (including the interviewee). Those who answered in the affirmative are considered to be nascent entrepreneurs. ${ }^{4}$ The share of this group in the population aged between 18 and 68 years is 3.7 percent.

Table I reports detailed results for the ten regions. Interregional differences in the order of magnitude point to differences in the level of entrepreneurial activity among the regions. The share of nascent entrepreneurs in the population is about twice as high in the regions Köln and München as in the regions Emscher-Lippe and Mittleres Mecklenburg.

\section{[Table I near here]}

On average in the ten regions 4.2 percent of the nascent entrepreneurs stated to be unemployed at the time of the interview. ${ }^{5}$ Table I shows that in our sample the share of unemployed among nascent entrepreneurs differs considerably between the ten regions. This share is zero in München and Stuttgart (two regions with a very low rate of unemployment according to official statistics), and 17 percent in the region Mittleres Mecklenburg (which suffers from a notoriously high unemployment rate).

As regards the share of nascent entrepreneurs among the unemployed we find pronounced interregional differences, too (see Table I). While this share is again zero in München and Stuttgart, it is more than three times the average of 4 percent in Köln, and only 1.26 percent in Westsachsen/Leipzig.

\section{Who intends to step from unemployment into self-employment?}

In this section the question what distinguishes nascent entrepreneurs from the rest of the unemployed is investigated econometrically. We test for the role played by both individual and regional factors in shaping the probability of becoming a nascent entrepreneur out of unemployment.

\footnotetext{
4 This definition of a nascent entrepreneur is identical to the definition used in the GEM project mentioned above; see Reynolds et al., 2000, p. 9.

5 Note that this self-classification as an unemployed can differ from the official definition of registered unemployed people for various reasons.
} 
To start with the individual factors, we will control for the role played by standard demographic variables, viz. sex; age (measured in years); and general human capital measured by the level of education (a dummy variable showing whether or not a person has a higher education, i.e. went to school for at least 12 years, or holds a degree). To investigate the impact of risk aversion and role models, two dummy variables are included in the empirical model: The survey asks whether the interviewee personally knows someone who started a new business during the last two years, and we look for a positive impact of contact with such a 'role model' (see Sternberg 2000, p. 60). Furthermore, the interviewee is asked whether fear to fail would prevent him from founding a firm. If he answered this question in the affirmative we consider this as an indicator of a high degree of risk aversion, and we expect a negative impact on the probability of becoming a nascent entrepreneur.

Descriptive statistics for these variables are given in Table II. Among the 380 unemployed interviewees we find 15 nascent entrepreneurs. In this (evidently, small) sample of nascent entrepreneurs the shares of males, people with higher education, and people with personal contact to a young entrepreneur are larger, and the the share of people who consider fear of failure to be a reason not to start a new business is smaller than among the rest of the unemployed. Furthermore, the nascent entrepreneurs are about 8 years younger on average.

\section{[Table II near here]}

The ceteris paribus role played by these characteristics in determining the probability of becoming a nascent entrepreneur is investigated in an econometric model with a dummy endogenous variable taking the value one if an unemployed person is a nascent entrepreneur, zero otherwis e. ${ }^{6}$ Results are reported in the column headed 'Model A' in Table III. From the prob-values ${ }^{7}$ it follows that according to this model (and in line with our priors) the probability of becoming a nascent entrepreneur diminishes with age, is lower for people with a high degree of risk aversion, and knowing a role model personally has a positive impact. According to these results both sex and higher education do not matter.

\section{[Table III near here]}

Model A considers the role of personal attributes and attitudes only. From the descriptive evidence reported in Table I we know that the level of entrepreneurial activity differs considerably between regions. If this points to interregional differences in what is often called 'entrepreneurial culture' we would expect that these differences influence the decisions taken by individuals living in a region. As a next

\footnotetext{
6 To take the survey design described in section 2 above into account, the models were estimated with Stata 7.0 using the survey probit program svyprobit with the region as the primary sampling unit (psu) to control for clustering; see StataCorp, 2001a, p. 321ff. for an overview of survey estimation.

${ }^{7}$ We report prob-values instead of t-values for two reasons: First, the degrees of freedom for the $t$ in svyprobit are the number of clusters (i.e., regions) minus one, and not the number of observations minus the number of estimated coefficients, and this might cause irritation; second, the prob-values give an immediate and exact imp ression of the empirical significance level of an estimated coefficient.
} 
step, therefore, we additionally test for the role played by the region in determining whether an unemployed person becomes a nascent entrepreneur or not.

Results for an augmented empirical model containing dummy variables for the regions (using the Emscher-Lippe region as the standard group) are reported in the column headed 'Model B' in Table III. Four estimated coefficients of the region dummies are statistically significant at an error level of 8.5 percent or better, and an adjusted Wald test of the null hypothesis that all these coefficients are zero rejects the null with a p-value of $0.0001 .^{8}$ Note that the estimated coefficients for the other variables included and their levels of significance do not differ much between Model A and Model B, with the exception of the sex dummy which, however, is not statistically different from zero in both models.

To peek inside the black box of the regional effects revealed by the dummies a third empirical model was estimated in which the dummy variables were substituted by two measures which mirror different aspects of the regional entrepreneurial culture: the share of nascent entrepreneurs, and the share of unemployed among nascent entrepreneurs in the population. A higher share of nascent entrepreneurs points to a better developed entrepreneurial culture in a region at the time of the survey, and we expect that this increases the probability of becoming a nascent entrepreneur. The same effect might be expected from a higher share of unemployed among the nascent entrepreneurs, signalling that many others are doing it right now, so I might expect to make it, too. To put it differently, the share of nascent entrepreneurs is included as a proxy variable that should bundle all those hard to measure elements that form the regional milieu - if a region has a well developed culture of entrepreneurship, and if this is better than in other regions, a higher share of nascent entrepeneurs should indicate this. A higher share of unemployed among nascent entrepreneurs, on the other hand, points to a business culture that is favourable (or, at least, less hostile) towards unemployed founders of small firms. However, one might expect that the share of unemployed among nascent entrepreneurs is higher in regions with a higher rate of unemployment, ceteris paribus. To control for this effect the share of unemployed in all interviewees in a region is included in the empirical model. We expect that survival tends to be harder for new firms in regions with a higher rate of unemployment, and, therefore, fewer (unemployed) people will work on building their own firm in such regions.

Results for this model are reported as 'Model C' in Table III. The estimated coefficients for both the regional share of nascent entrepreneurs and the regional share of unemployed among nascent entrepreneurs have the expected sign, and both are highly significant statistically. The estimated coefficient of the regional share of unemployed interviewees is negative and statistically significant at a conventional level. All these results are in line with our priors. The big picture from the results for the personal characteristics and attitudes is the same as in Model B: The probability of becoming a nascent

\footnotetext{
8 Note that the dummies for the regions "Stuttgart" and "München" are dropped because there are no nascent entrepreneurs stepping out of unemployment from these regions in our sample (see above). The associated observations for unemployed interviewees from these regions who are no nascent entrepreneurs are dropped, too. This has no effect at all on the likelihood or estimates of the remaining coefficients and increases the numerical stability of the optimization process (see StataCorp 2001b, p. 581).
} 
entrepreneur out of unemployment is higher for those who personally know a role model; it is lower for older people and for people with a high risk aversion.

Discussion of results hitherto was limited to the statistical significance of the estimated coefficients and the direction of influence conducted by the variables. Information on the extent of this influence, or on the economic significance, however, is even more important. Evidently, a variable that has no statistically significant impact can be ignored from an economic point of view, but the opposite is not true: A variable that is highly significant statistically might not matter at all economically - if the estimated probability for becoming a nascent entrepreneur out of unemployment diminishes by 0.00001 percent when a person is 68 instead of 18 years old, we can ignore age of a person in any discussion on nascent entrepreneurs irrespective of any high level of statistically significance indicated by the probvalue.

Unfortunately, the estimated coefficients from a probit model (or for any other non-linear model) can not easily be used for statements about the size of the ceteris paribus effect of a change of the value of an exogenous variable (e.g., an increase in the age of a person by five years) on the value of the endogenous variable (e.g., the probability of becoming a nascent entrepreneur out of unemployment), because the size of this effects depends on both the value of the exogenous variable under consideration and on the values of all other variables in the model (see Long and Freese, 2001, 87ff.).

One way to ease interpretation of the estimation results is to compute the estimated values of the endogenous variable (here: the probability of becoming a nascent entrepreneur out of unemployment) for a person with certain characteristics and attitudes (male, 38 years old, with higher education, etc.), and then to see how a change in the value of one exogenous variable (e.g., the age) changes the estimated probability. With a lot of exogenous variables this procedure tends to lead to results not easy to survey.

A way out is to construct a limited number of types of persons using dichotomous variables and to summarize the estimation results for various values of a significant continous variable in a figure, holding the values for the other continous variables constant (usually, at their sample means).

For expository purposes, we focus on men with higher education. Furthermore, for the moment we fix the three regional variables at their sample means. Next, we use combinations of the two dichotomous variables, high degree of risk aversion and personal contacts with a role model, to form four types of persons labeled TYP A to TYPE D and listed in Table IV. For every type the estimated probability of becoming a nascent entrepreneur out of unemployment is then computed for values of the age variable between 18 and $62 .^{9}$

\section{[Table IV near here]}

\footnotetext{
9 The computations were limited to an age of 62 years because the oldest interviewee reporting to be unemployed was 62 years old in our sample. All computations and graphics are done using SPost, an addon package of ado-files for Stata written by J. Scott Long and Jeremy Freese (Scott and Freese 2001). Note that SPost does not work with Stata's svyprobit program, so the model has been reestimated using Stata's probit program with the option 'cluster', using the region as a cluster. The estimated coefficients that are needed to calculate the estimated probabilities are numerically identical for svyprobit and probit with this cluster option.
} 
Results are graphed in figure 1. From this it is obvious that age matters. For any given value of age, the probability to start a new business is much higher for a TYPE C person (who has no high risk aversion, and personally knows a young entrepreneur) than for any other person considered. This demonstrates that these statistically significant variables have an economically important impact, too. Note that TYPE D and TYPE A have rather similar estimated probabilities although they are 'the opposite' regarding both high risk aversion and contacts with a young entrepreneur. This illustrates that the opposite effects of different determinants of becoming a nascent entrepreneur out of unemployment can net out.

[Figure 1 near here]

The ceteris paribus impact of the statistically significant variable "share of nascent entrepreneurs in a region" is llustrated by comparing the results for a certain type of person (a man with higher education, personal contacts with a role model, and a high level of risk aversion) from a (fictitious) region with an average share of unemployed among nascent entrepreneurs and an average share of unemployed in all interviewees at three different level of age (viz., 22, 42, and 62 years) for different values of the regional share of nascent entrepreneurs between 1.95 percent and 5.87 percent (the minimum and maximum value of the variable in our sample, respectively). The estimated probability of becoming a nascent entrepreneur out of unemployment increases with an increasing share of nascent entrepreneurs in the region, and it is allways higher for younger persons than for older. A 22 year old person with the characteristics stated above has an estimated probability of becoming a nascent entrepreneur of 0.07 in the region with the lowest share of nascent entrepreneurs, while for a person with identical characteristics from the region with the highest share of nascent entrepreneurs the estimated probabilty is 0.26 (see figure 2).

[Figure 2 near here]

Next we illustrate the role of the share of unemployed in the region. We consider the same type of person (a man with higher education, personal contacts with a role model, and a high level of risk aversion) as before, but put him in a (fictitious) region with an average share of both nascent entrepeneurs and unemployed among nascent entrepreneurs in all interviewees, and we look at him at three different level of age (viz., 22, 42, and 62 years). We let the regional share of unemployed among all interviewees vary between 1.85 percent and 12.53 percent (the minimum and maximum value of this share in our sample, respectively). The estimated probability of becoming a nascent entrepreneur out of unemployment decreases with an increasing share of unemployed in the region, and it is allways higher for younger persons than for older. A 22 year old person with the characteristics stated above has an estimated probability of becoming a nascent entrepreneur of 0.15 in the region with the lowest share of 
unemployed, while for a person with identical characteristics from the region with the highest share of unemployed the estimated probabilty is 0.08 (see figure 3 ).

[Figure 3 near here]

The last step in our interpretation of the estimates from model "C" considers the ceteris paribus impact of the statistically significant variable "share of unemployed among the nascent entrepreneurs in a region". This effect is illustrated by comparing the results for the now familar type of person (defined above) from a (fictitious) region with an average share of nascent entrepreneurs and an average share of unemployed in all interviewees at three different evel of age (viz., 22, 42, and 62 years) for different values of the regional share of unemployed among nascent entrepreneurs between zero percent and 17.06 percent (the minimum and maximum value of the variable in our sample, respectively). The estimated probability of becoming a nascent entrepreneur out of unemployment increases with an increasing share of unemployed among the nascent entrepreneurs in the region, and it is allways higher for younger persons than for older. A 22 year old person with the characteristics stated above has an estimated probability of becoming a nascent entrepreneur of 0.05 in the region with the lowest share of unemployed among the nascent entrepreneurs, while for a person with identical characteristics from the region with the highest share of unemployed among nascent entrepreneurs the estimated probabilty is 0.23 (see figure 4).

[Figure 4 near here]

These interpretative computations illustrate that both proxies for the entrepreneurial regime are not only statistically significant, but economically important, too.

\section{Conclusions}

This paper empirically investigates two hitherto neglected issues: What is the role played by risk aversion and personal contact with a role model in shaping the decision to step from unemployment to selfemployment (controlling for standard demographic variables, i.e. sex, age, and education)? And given the personal characteristics and attitudes, how does the regional 'entrepreneurial milieu' affect the decision to start a new business out of unemployment? Based on data from a recent representative survey of the population in ten German planning regions it is shown that a high degree of risk aversion and lack of personal contact with a young entrepreneur reduce the probability of starting one's own business. Furthermore, it turns out that a favourable 'regional entrepreneurial milieu' (proxied by higher levels of current start-up activity and larger shares of unemployed among the starters in a region) has a positive effect on the individual propensity to step into self-employment. All these impacts are not only statistically significant, but economically important, too. 


\section{References}

Bundesamt für Bauwesen und Raumordnung, 2001, Aktuelle Daten zur Entwicklung der Städte, Kreise und Gemeinden, Ausgabe 2000, Bonn: Bundesamt für Bauwesen und Raumordnung.

Fritsch, Michael et al., 2001, 'Gründungen in Deutschland: Datenquellen, Niveau und räumlich-sektorale Struktur', Freiberg Working Papers \#12/2001, Technical University Bergakademie Freiberg, Faculty of Economics and Business Administration.

Japsen, Andrea and Heiko Bergmann, 2001, 'Regionaler Entrepreneurship Monitor (REM) - Konzept und erste Ergebnisse', Working Paper 253, Department of Economics and Social Sciences, University of Lueneburg, December.

Long, J. Scott and Jeremy Freese, 2001, Regression Models for Categorical Dependent Variables using Stata, College Station, TX: Stata Press.

Pfeiffer, Friedhelm and Frank Reize, 2000a, 'Business start-ups by the unemployed - an econometric analysis based on firm data', Labour Economics 7, 629-663.

Pfeiffer, Friedhelm and Frank Reize, 2000b, 'From Unemployment to Self-Employment - Public Promotion and Selectivity', International Journal of Sociology 30, 3, 71-99.

Pfeiffer, Friedhelm, 1999, 'Existenzgründerpotentiale unter Arbeitssuchenden: Empirische Evidenz auf der Basis des Mikrozensus', Mitteilungen aus der Arbeitsmarkt- und Berufsforschung 32, 300-314.

Reize, Frank, 2000, 'Leaving Unemployment for Self-employment', Center for European Economic Research, Discussion Paper No. 00-26, July.

Reynolds, Paul D. et al., 2000, GEM Global Entrepreneurship Monitor. 2000 Executive Report, Kansas City: Kauffman Center for Entrepreneurial Leadership.

StataCorp, 2001a, Stata User's Guide, Release 7, College Station, TX: Stata Corporation.

StataCorp, 2001b, Stata Reference Manual, Release 7, Volume 2, College Station, TX: Stata Corporation.

Sternberg, Rolf, 2000, Entrepreneurship in Deutschland, Das Gründungsgeschehen im internationalen Vergleich, Länderbericht Deutschland 1999 zum Global Entrepreneurship Monitor, Berlin: edition sigma.

Sternberg, Rolf et al., 2000, Global Entrepreneurship Monitor Länderbericht Deutschland 2000, Köln: Wirtschafts - und Sozialwissenschaftliches Institut, Universität zu Köln.

Sternberg, Rolf et al., 2001, Global Entrepreneurship Monitor Länderbericht Deutschland 2001, Köln: Wirtschafts - und Sozialwissenschaftliches Institut, Universität zu Köln.

Wießner, Frank, 2000, 'Erfolgsfaktoren von Existenzgründungen aus der Arbeitslosigkeit', Mitteilungen aus der Arbeitsmarkt- und Berufsforschung 33, 518-532.

Wießner, Frank, 2001, Arbeitslose werden Unternehmer, Beiträge zur Arbeitsmarkt- und Berufsforschung BeitrAB 241, Nürnberg: Institut für Arbeitsmarkt- und Berufsforschung der Bundesanstalt für Arbeit. 
Table I: Interregional distribution of selected entrepreneurial activities 1

\begin{tabular}{|c|c|c|c|}
\hline Region & $\begin{array}{l}\text { Share of "nascent } \\
\text { entrepreneurs" } \\
\text { in the population } \\
\text { (percent) }\end{array}$ & $\begin{array}{c}\text { Share of unemployed } \\
\text { among } \\
\text { "nascent entrepreneurs" } \\
\text { (percent) }\end{array}$ & $\begin{array}{c}\text { Share of "nascent } \\
\text { entrepreneurs" } \\
\text { among unemployed } \\
\text { (percent) }\end{array}$ \\
\hline Emscher-Lippe & 2.53 & 9.89 & 5.65 \\
\hline Köln & 5.87 & 7.87 & 12.79 \\
\hline Lüneburg & 4.25 & 3.52 & 4.03 \\
\hline Main-Rhön & 3.11 & 4.44 & 5.22 \\
\hline Mittelhessen & 2.63 & 3.79 & 3.08 \\
\hline Mittleres Mecklenburg & 1.95 & 17.06 & 3.34 \\
\hline München & 4.63 & 0.00 & 0.00 \\
\hline Schleswig-Holstein Mitte & 3.61 & 6.09 & 5.62 \\
\hline Stuttgart & 2.92 & 0.00 & 0.00 \\
\hline Westsachsen/Leipzig & 2.55 & 6.08 & 1.26 \\
\hline Average & 3.74 & 4.20 & 4.01 \\
\hline
\end{tabular}

Source: Own calculations based on weighted data from the Regional Entrepreneurship Monitor REM Survey 2001

1 For a definition of the groups in " " see text. 


\section{Table II: Descriptive statistics 1}

\begin{tabular}{|c|c|c|c|c|c|c|}
\hline \multirow[b]{2}{*}{ Variable } & \multicolumn{2}{|c|}{ All } & \multicolumn{2}{|c|}{ Nascent entrepreneurs } & \multicolumn{2}{|c|}{ Others } \\
\hline & Mean & Std. & Mean & Std. & Mean & Std. Dev. \\
\hline Sex (Dummy, $1=$ Male) & 0.46 & 0.50 & 0.53 & 0.52 & 0.46 & 0.50 \\
\hline Age (Years) & 42.71 & 11.86 & 34.80 & 9.33 & 43.03 & 11.85 \\
\hline Higher education (Dummy, 1 = Yes) & 0.23 & 0.42 & 0.40 & 0.51 & 0.22 & 0.42 \\
\hline Fear of failure a reason not to start (Dummy, $1=$ Yes) & 0.58 & 0.49 & 0.27 & 0.46 & 0.59 & 0.49 \\
\hline Personal contact with a young entrepreneur (Dummy, $1=$ Yes) & 0.35 & 0.48 & 0.73 & 0.46 & 0.34 & 0.47 \\
\hline Regional share of nascent entrepeneurs $\left(\frac{\circ}{0}\right)$ & 3.05 & 1.11 & 3.76 & 1.49 & 3.02 & 1.08 \\
\hline Regional share of unemployment (\%) & 7.11 & 4.11 & 5.14 & 3.04 & 7.19 & 4.13 \\
\hline Regional share of unemployed in nascent entrepreneurs ( $\frac{\circ}{0}$ ) & 7.93 & 5.21 & 7.93 & 4.25 & 7.93 & 5.25 \\
\hline Number of cases & 380 & & 15 & & 365 & \\
\hline
\end{tabular}

Source: Own calculations based on data from the Regional Entrepreneurship Monitor REM Survey 2001

1 For a detailed definition of the variables see text. 


\section{Table III: Estimation results for determinants of becoming a nascent entrepreneur out of unemployment 1}

\begin{tabular}{|c|c|c|c|c|c|c|}
\hline Variable & $\begin{array}{l}\text { Moc } \\
\text { Coeff. }\end{array}$ & $\begin{array}{l}\mathrm{A} \\
\mathrm{P}>|\mathrm{t}|\end{array}$ & $\begin{array}{l}\text { Mod } \\
\text { Coeff. }\end{array}$ & $\begin{array}{l}B \\
P>|t|\end{array}$ & $\begin{array}{r}\text { Mo } \\
\text { Coeff. }\end{array}$ & $\begin{array}{l}\mathrm{C} \\
\mathrm{P}>|t|\end{array}$ \\
\hline Sex (Dummy, $1=$ Male) & -0.0017 & 0.995 & 0.0483 & 0.881 & 0.0162 & 0.957 \\
\hline Age (Years) & -0.0229 & 0.015 & -0.0250 & 0.025 & -0.0230 & 0.025 \\
\hline Higher education (Dummy, $1=$ Yes) & 0.3353 & 0.230 & 0.3635 & 0.196 & 0.2975 & 0.211 \\
\hline Fear of failure a reason not to start (Dummy, $1=$ Yes) & -0.5648 & 0.073 & -0.5932 & 0.094 & -0.5500 & 0.086 \\
\hline Personal contact with a young entrepreneur (Dummy, 1 = Yes) & 0.6650 & 0.024 & 0.7310 & 0.046 & 0.6724 & 0.037 \\
\hline Regional share of nascent entrepeneurs $\left(\frac{\circ}{0}\right)$ & & & & & 0.2048 & 0.004 \\
\hline Regional share of unemployment (\%) & & & & & -0.0372 & 0.054 \\
\hline Regional share of unemployed among nascent entrepeneurs ( $\frac{\circ}{\circ}$ ) & & & & & 0.0538 & 0.008 \\
\hline Region Köln (Dummy, 1 = Yes) & & & 0.5448 & 0.002 & & \\
\hline Region Lüneburg (Dummy, 1 = Yes) & & & -0.1152 & 0.167 & & \\
\hline Region Main-Rhön (Dummy, 1 = Yes) & & & -0.2256 & 0.346 & & \\
\hline Region Mittelhessen (Dummy, 1 = Yes) & & & 0.0190 & 0.835 & & \\
\hline Region Mittleres Mecklenburg (Dummy, 1 = Yes) & & & -0.2378 & 0.022 & & \\
\hline Region Schleswig-Holstein Mitte (Dummy, 1 = Yes) & & & -0.1174 & 0.085 & & \\
\hline Region Westsachsen/Leipzig (Dummy, 1 = Yes) & & & -0.5489 & 0.001 & & \\
\hline Constant & -1.0528 & 0.030 & -0.8990 & 0.029 & -1.9332 & 0.008 \\
\hline Number of cases & \multicolumn{2}{|c|}{380} & \multicolumn{2}{|c|}{351} & \multicolumn{2}{|c|}{380} \\
\hline
\end{tabular}

1 The models were estimated by stata 7 using the program svyprobit with the region as a cluster. 
Table IV: Types of persons for simulations 1

\begin{tabular}{|c|c|c|c|c|c|}
\hline Variable & Type & A & $\mathrm{B}$ & $\mathrm{C}$ & $\mathrm{D}$ \\
\hline Sex (Dummy, $1=$ Male) & & 1 & 1 & 1 & 1 \\
\hline Higher education (Dummy, 1 = Yes) & & 1 & 1 & 1 & 1 \\
\hline Fear of failure a reason not to start (Dummy, 1 = Yes) & & 1 & 1 & 0 & 0 \\
\hline Personal contact with a young entrepreneur (Dummy, 1 = Yes) & & 1 & 0 & 1 & 0 \\
\hline Regional share of nascent entrepeneurs $\left(\frac{\circ}{0}\right)$ & & 3.05 & 3.05 & 3.05 & 3.05 \\
\hline Regional share of unemployment ( $\left.\frac{\circ}{0}\right)$ & & 7.11 & 7.11 & 7.11 & 7.11 \\
\hline Regional share of unemployed among nascent entrepreneurs (\%) & & 7.93 & 7.93 & 7.93 & 7.93 \\
\hline
\end{tabular}

1 For a detailed definition of the variables see text. 
Figure 1: Estimated probability for becoming a nascent entrepreneur Out of unemployment for various types of persons ${ }^{1}$

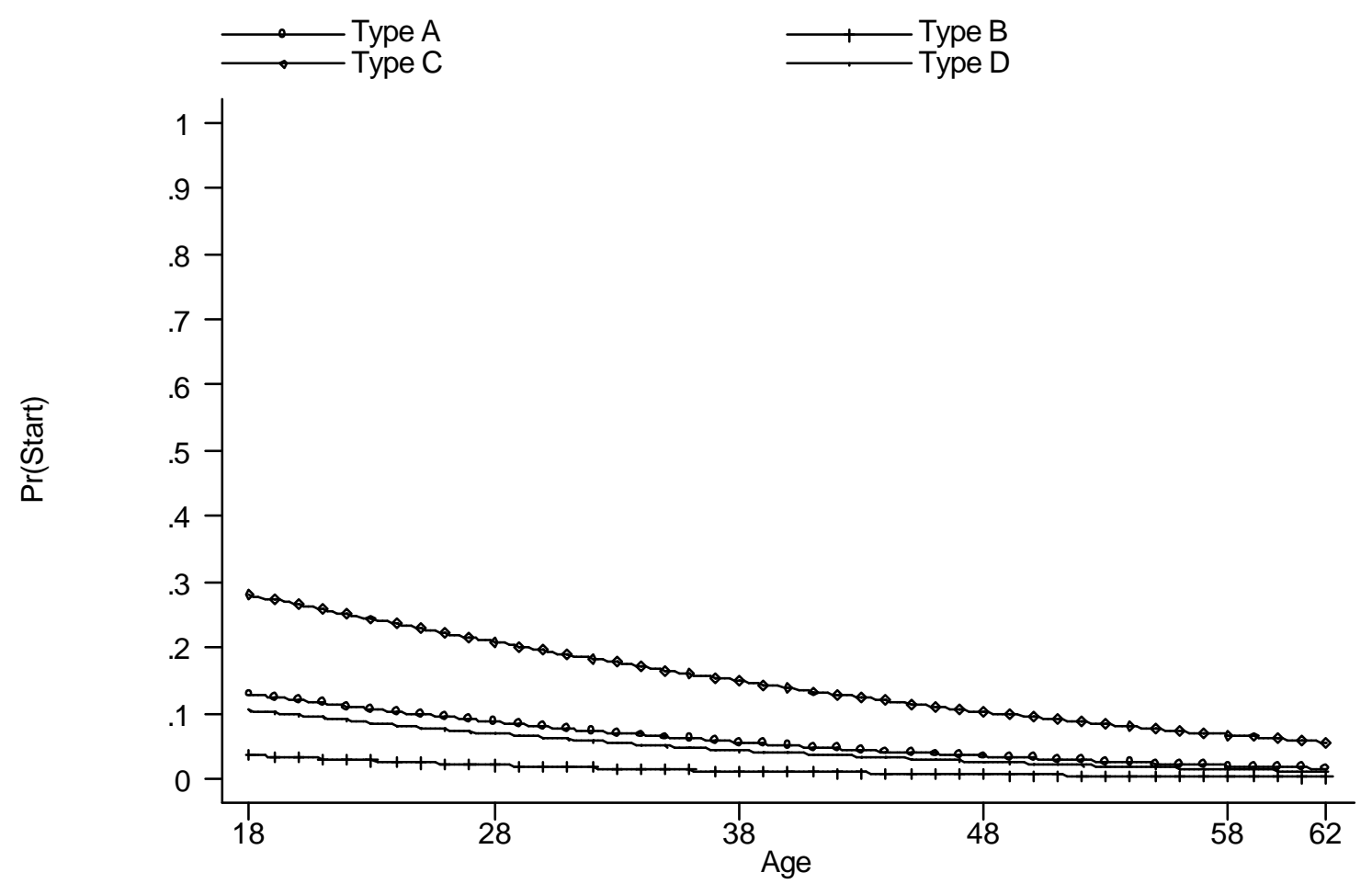

\footnotetext{
${ }^{1}$ For a definition of types of persons see table IV
} 
Figure 2: Estimated probability for becoming a nascent entrepreneur out of unemployment in regions with different shares of nascent entrepreneurs ${ }^{1}$

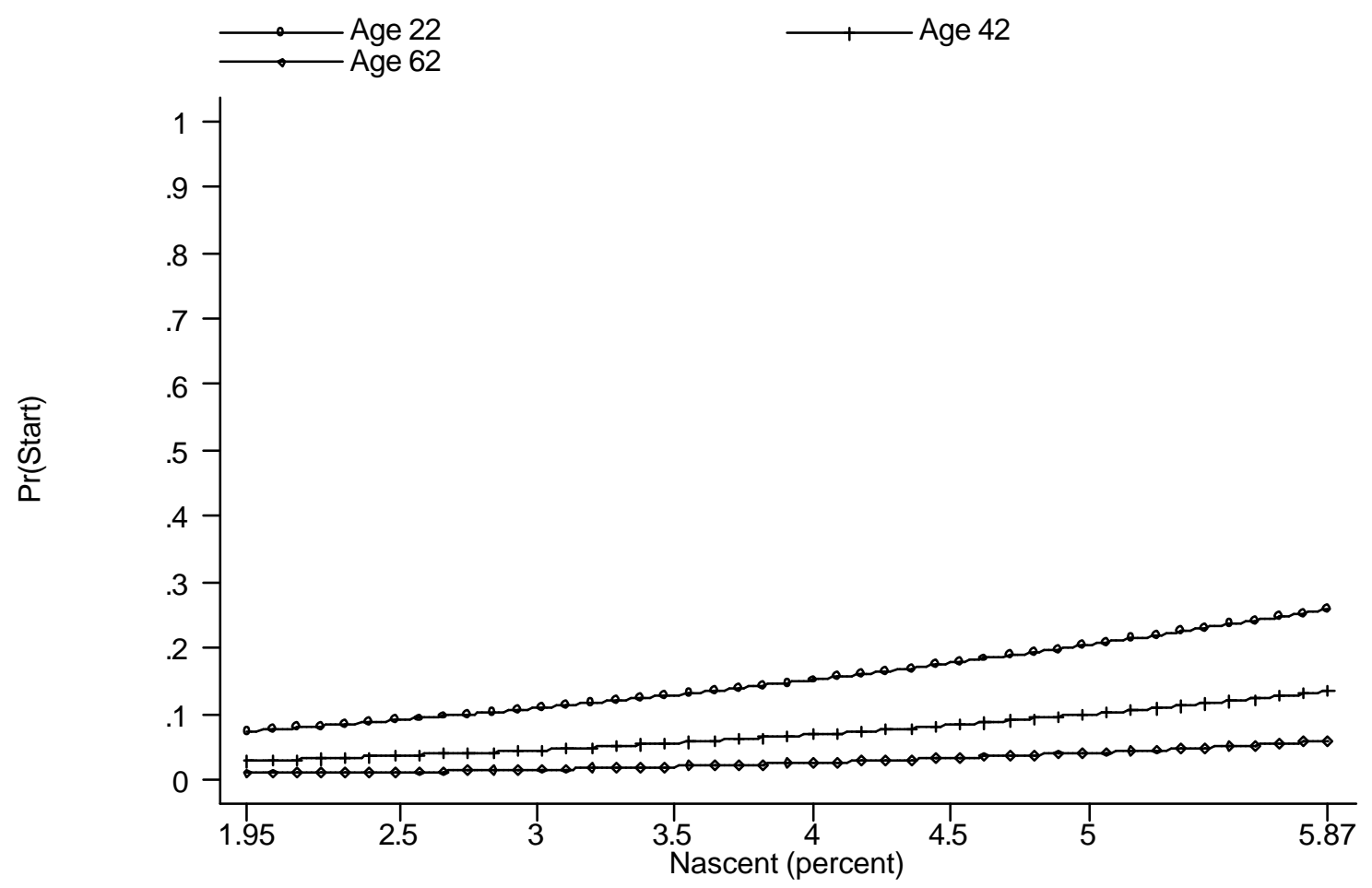

${ }^{1}$ For a description of the type of person considered see text 
Figure 3: Estimated probability for becoming a nascent entrepreneur out of unemployment in regions with different rates of unemployment ${ }^{1}$

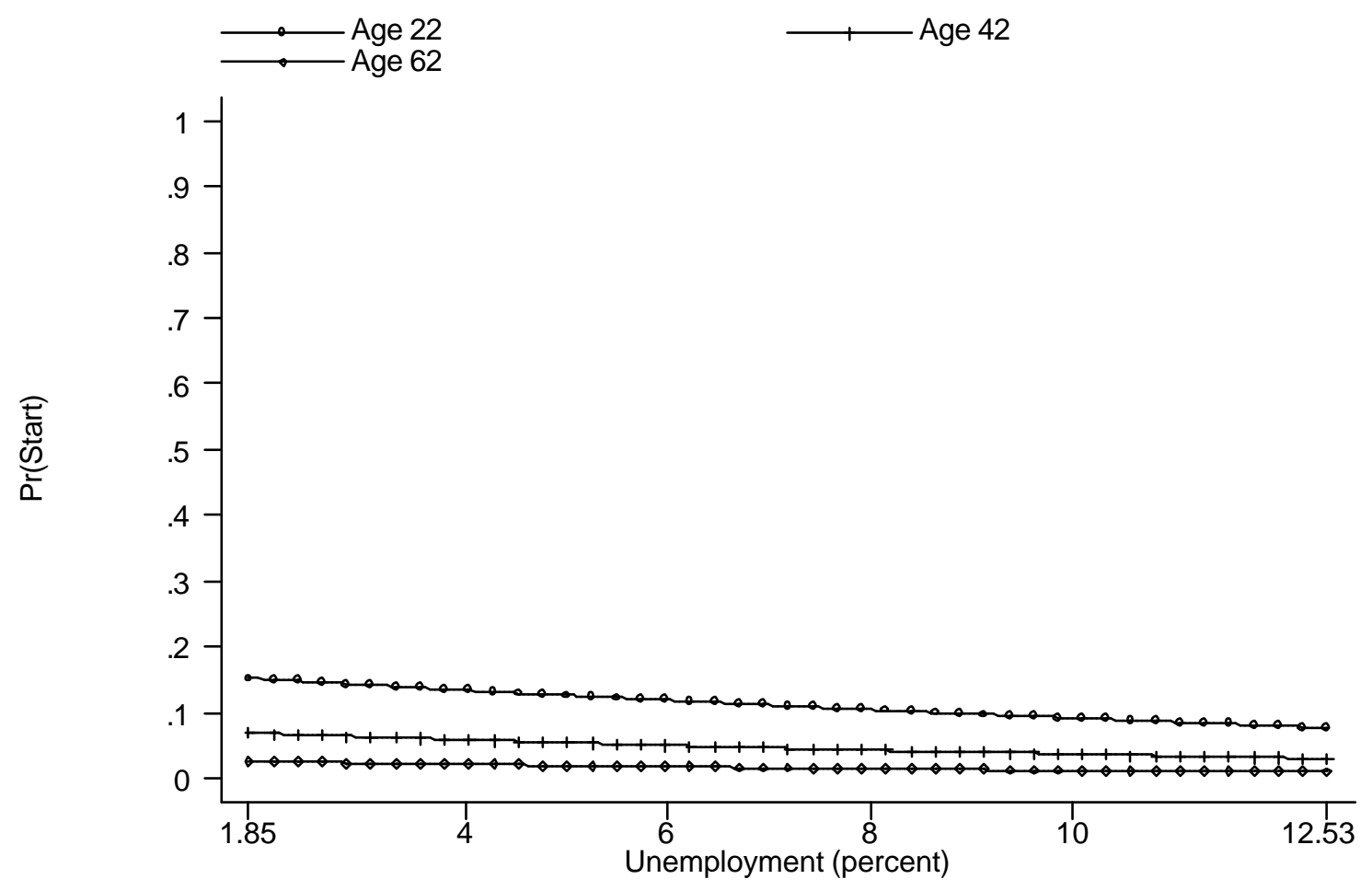

${ }^{1}$ For a description of the type of person considered see text 
Figure 4: Estimated probability for becoming a nascent entrepreneur out of unemployment in regions with different shares of unemployment among nascent entrepreneurs ${ }^{1}$

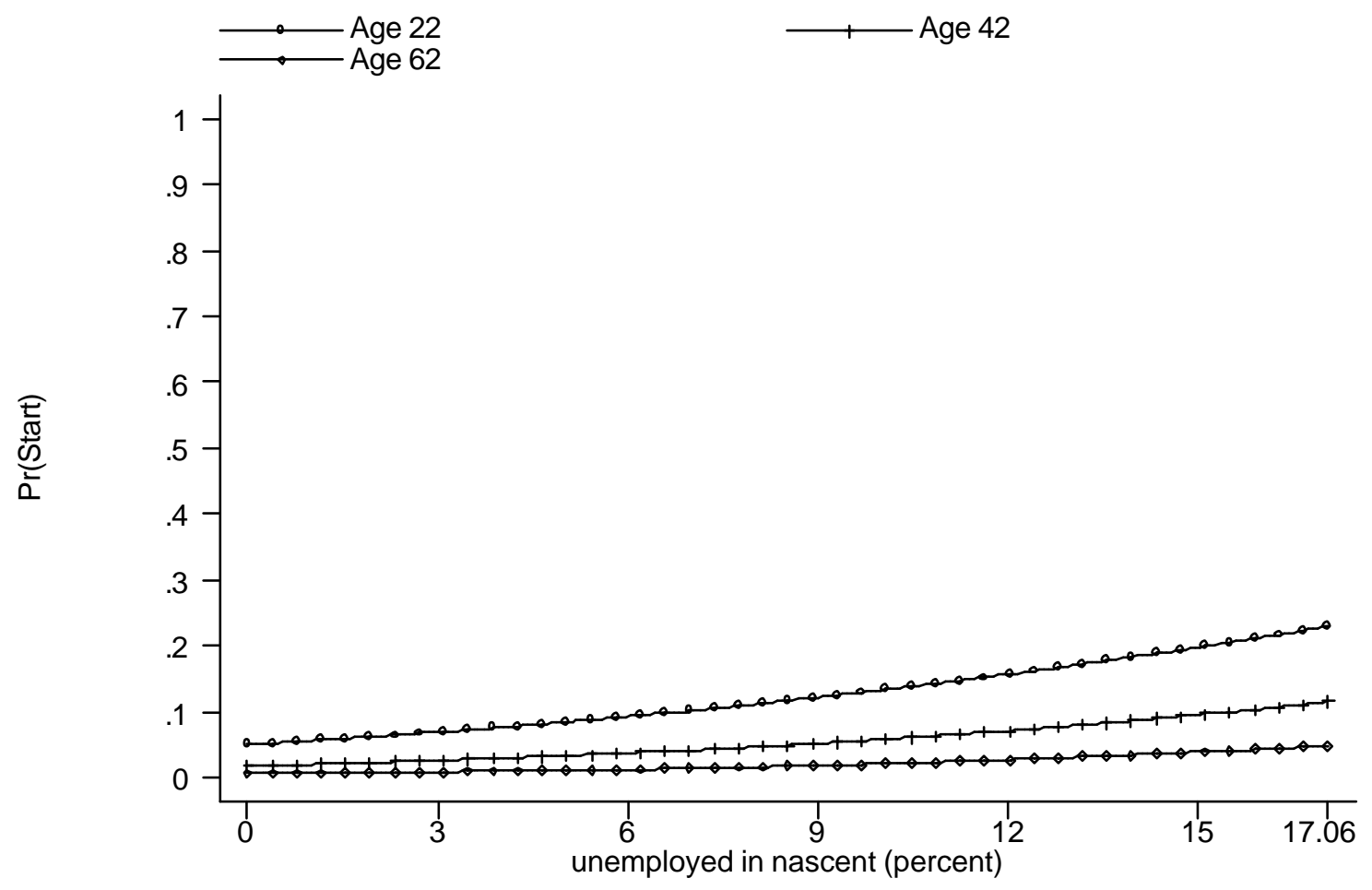

\footnotetext{
${ }^{1}$ For a description of the type of person considered see text
} 


\section{IZA Discussion Papers}

No.

Author(s)

P. Carneiro

K. T. Hansen

J. J. Heckman

454

W. Koeniger

J. T. Addison

C. R. Belfield

T. M. Andersen

M. Lindeboom

M. Kerkhofs
W. Schnedler

U. Sunde
M. Galeotti
L. J. Maccini
F. Schiantarelli

M. Biewen

B. R. Chiswick

Y. Liang Lee

P. W. Miller

M. Gurgand

D. N. Margolis

B. R. Chiswick

Y. Liang Lee

P. W. Miller

E. Wasmer

J. Ermisch

M. Francesconi

J. E. Askildsen

E. Bratberg

$\varnothing$. A. Nilsen
A. Venturini
C. Villosio

J. Wagner
Title

Area

Date

Removing the Veil of Ignorance in Assessing the

6

Distributional Impacts of Social Policies

Defensive Innovations

5

03/02

Unions and Establishment Performance:

3

Evidence from the British Workplace Industrial/

Employee Relations Surveys

International Integration, Risk and the Welfare State

Health and Work of the Elderly: Subjective Health Measures, Reporting Errors and the Endogenous Relationship between Health and Work

Inventories, Employment and Hours

The Covariance Structure of East and West German Incomes and its Implications for the Persistence of Poverty and Inequality

Family Matter: The Role of the Family in Immigrants' Destination Language Acquisition

Welfare and Labor Earnings:

03/02

An Evaluation of the Financial Gains to Work

The Determinants of the Geographic
Concentration among Immigrants: Application to Australia

Labor Supply Dynamics, Unemployment and Human Capital Investments

$03 / 02$

03/02

The Hold-Down Problem and the Boundaries of the Firm: Lessons from a Hidden Action Model with Endogenous Outside Option

Intergenerational Social Mobility and Assortative

04/02 Mating in Britain

Unemployment, Labour Force Composition and Sickness Absence: A Panel Data Study

Are Immigrants Competing with Natives in the 1 Italian Labour Market? The Employment Effect

The Impact of Risk Aversion, Role Models, and

Unemployment to Self-Employment: Empirical Evidence for Germany 